\title{
PEMANFAATAN SUMBER DAYA HUTAN OLEH MASYARAKAT DI SEKITAR TAMAN NASIONAL KUTAI
}

\author{
Rahmah $^{1}$, Yaya Rayadin ${ }^{2}$, dan Marlon Ivanhoe Aipassa ${ }^{2}$ \\ ${ }^{1}$ Ilmu Kehutanan, Fakultas Kehutanan, Universitas Mulawarman, Indonesia. \\ ${ }^{2}$ Fakulltas Kehutanan Universitas Mulawarman. Jl. Ki Hajar Dewantara, Gunung Kelua, \\ Samarinda 75116, Kalimantan Timur, Indonesia.Tel.: +62-541-735089, Fax.: +62-541- \\ 735379. \\ E-Mail: ${ }^{1}$ rahmah.jinarto@gmail.com; ${ }^{2}$ yrayadin@yahoo.com; \\ ${ }^{3}$ marlon.ivanhoe@gmail.com
}

\begin{abstract}
ABSTRAK
Pemanfaatan Sumber Daya Hutan oleh Masyarakat di Sekitar Taman Nasional Kutai. Kondisi masyarakat di sekitar TN Kutai perlu mendapat perhatian karena bisa berpengaruh terhadap kondisi TN Kutai baik langsung maupun tidak langsung.Data pemanfaatan sumber daya hutan oleh masyarakat sekitar kawasan bisa menjadi rujukan untuk pengelolaan TN Kutai yang lestari dan memperhatikan masyarakat sekitar.Tujuan penelitian ini adalah (1) Mengetahui pemanfaatan sumber daya hutan oleh masyarakat desa sekitar TN Kutai; (2) Mengetahui kontribusi pendapatan dari hasil hutan terhadap pendapatan totalmasyarakat desa sekitar TN Kutai. Lokasi penelitian merupakan desa yang penduduknya bermukim di sekitar Taman Nasional Kutai SPTN Wilayah II dan ada informasi awal tentang pemanfaatan sumber daya hutan oleh penduduk.Lokasi penelitian adalah 5 desa di sisi barat TN Kutai yaitu Desa Menamang Kanan dan Desa Menamang Kiri di Kabupaten Kutai Kartanegara serta Desa Mawai Indah, Desa Beno Harapan dan Desa Himba Lestari di Kabupaten Kutai Timur. Metode penelitian ini adalah accidental sampling.Responden adalah kepala rumah tangga yang dipilih secara acak tersebar di areal pemukimandengan intensitas sampel $10 \%$.Pemanfaatan sumber daya hutan oleh masyarakat berupa pengambilan tumbuhan dan satwa liar (TSL) bernilai ekonomis tinggi antara lain ulin, meranti, payau, kijang dan kancil. Lokasi pengambilanTSL sangat dekat dengan kawasan TN Kutai. sehingga dikhawatirkan mengancam kelestarian kawasan TN Kutai. Pendapatan dari hasil hutandan kontribusi terhadap pendapatan total responden dari yang tertinggihingga paling rendah adalah : (1) Desa Himba Lestari sebesar Rp36.700.000,- (70,04\%); (2) Desa Beno Harapan sebesar Rp26.550.000,- (26,81\%); (3) Desa Mawai Indah sebesar Rp27.000.000,- (25,27\%); (4) Desa Menamang Kanan sebesar Rp6.700.000,- (4,89\%). Desa Menamang Kiri tidak ada pendapatan dari hasil hutan.
\end{abstract}

Kata kunci : Taman Nasional, Kutai, sumber daya, hutan, pemanfaatan.

\begin{abstract}
Utilization of Forest Resources by Villagers Around Kutai National Park. The condition of the community around Kutai NP needs attention because it can affect the condition of Kutai NP both directly and indirectly. Data on the use of forest resources by the community around the area can be a reference for sustainable management of Kutai NP. The objectives of this study are (1) Determine the utilization of forest resources by the villagers around Kutai NP; (2) Determine the contribution of income from forest products to the total income of rural communities around Kutai NP. The research location arevillages whose inhabitants live around the Kutai National Park SPTN Region II and there is preliminary information about the use of forest resources by the population. The study sites were 5 villages on the west side of Kutai National Park namely Menamang Kanan and Menamang Kiri Villages in Kutai Kartanegara District and Mawai Indah, Beno Harapan and Himba Lestari Villages in East Kutai Regency. This research method is accidental sampling. Respondents are randomly selected household heads scattered in residential areas with a sample intensity of $10 \%$.Utilization of forest resources by the community in the form of extraction of wild plants and animals of high economic value include ulin, meranti, brackish, deer and mouse deer. The TSL collection location is very close to the Kutai National Park area. so it is threatening the preservation of the Kutai NP area. Revenues from forest products and contributions to the total income of respondents from the highest to
\end{abstract}


the lowest are: (1) Himba Lestari Village in the amount of Rp36,700,000 (70.04\%); (2) Beno Harapan Village in the amount of IDR26,550,000 (26.81\%); (3) Mawai Indah Village in the amount of Rp.27,000,000 (25.27\%); (4) Menamang Kanan Village in the amount of IDR 6,700,000 (4.89\%). Desa Menamang Kiri has no income from forest products.

Key words : National park, Kutai, resources, forest, utilization.

\section{PENDAHULUAN}

Hasil hutan yaitu benda-benda hayati, nonhayati dan turunannya, serta jasa yang berasal dari hutan (UU 41/1999 tentang Kehutanan). Selanjutnya pengertian tentang sumber daya alam hayati disebutkan dalam Peraturan Pemerintah Republik Indonesia Nomor 28 Tahun 2011 tentang Pengelolaan Kawasan Suaka Alam Dan Kawasan Pelestarian Alam, adalah unsur-unsur hayati di alam yang terdiri atas sumber daya alam nabati (tumbuhan) dan sumber daya alam hewani (satwa) yang bersamasama dengan unsur non hayati di sekitarnya secara keseluruhan membentuk ekosistem. Tumbuhan dan satwa liar merupakan bagian dari sumber daya alam hayati yang dapat dipergunakan untuk sebesar-besarnya kemakmuran rakyat, dan pemanfaatannnya dilakukan dengan memperhatikan kelangsungan potensi, daya dukung dan keanekaragaman jenis tumbuhan dan satwa liar (Anonim, 1999).

Taman Nasional Kutai di Provinsi Kalimantan Timur secara administrasi pemerintahan terletak di Kota Bontang $(0,36 \%)$, Kabupaten Kutai Kartanegara $(12,88 \%)$ dan Kabupaten Kutai Timur $(86,75 \%)$. Secara geografis Taman Nasional Kutai terletak di $0^{\circ} 7^{\prime} 54^{\prime \prime}$ 0³3'53" Lintang Utara dan 116 $58^{\circ} 48^{\prime}$ " 117³5'29" Bujur Timur. Berdasarkan SK Menteri Kehutanan Nomor : 4194/Menhut-VII/KUH/2014 tanggal 10 Juni 2014 tentang Penetapan Kawasan Hutan Taman Nasional Kutai, luasan Taman Nasional Kutai adalah 192.709,55 ha (Anonim, 2017). Peta kondisi Taman Nasional Kutai dan daerah penyangga di sekitarnya dapat dilihat pada Gambar 1 .

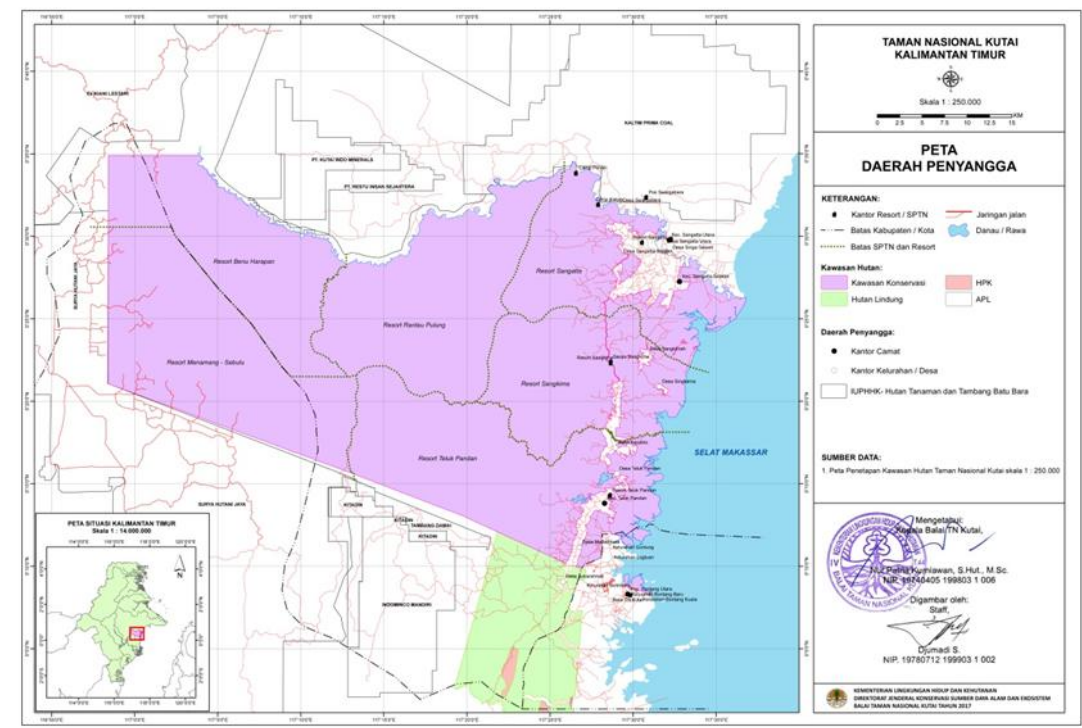

Gambar 1. Peta Taman Nasional Kutai dan Daerah Penyangga 
Kondisi yang diinginkan pada pengelolaan TN Kutai sebagaimana yang dituangkan dalam Rencana Pengelolaan Jangka Panjang TN Kutai 2018 - 2027 di antaranya fungsi pengawetan berjalan dengan baik.Pengawetan adalah upaya untuk menjaga agar keanekaragaman jenis tumbuhan dan satwa beserta ekosistemnya baik di dalam maupun di luar habitatnya tidak punah.Selain itu diharapkan fungsi pemanfaatan sumber daya alam hayati dan ekosistemnya dapat dinikmati oleh masyarakat dengan baik, yaitu yang berupa pemanfaatan hasil hutan non kayu maupun pemanfaatan jasa lingkungan.

Keberhasilan pengelolaan kawasan konservasi bergantung pada dukungan dan penghargaan masyarakat sekitarnya (Nugraha dan Murtijo, 2005 dalam Iswandono, 2007). Bila pelestarian bermanfaat bagi masyarakat sekitar maka masyarakat akan mau bekerja sama dengan pengelola dalam rangka pelestarian. Bentuk manfaat bagi masyarakat yaitu pemanfaatan terbatas pada sumberdaya tertentu, hak tradisional dan kebiasaan budaya, preferensi khusus untuk memperoleh pekerjaan dan pelayanan sosial dalam batas-batas yang masih dapat ditoleransi fungsi perlindungan kawasannya (Mackinnon et al. 1986 dalam Iswandono, 2007).

Taman Nasional Kutai sebagai salah satu kawasan konservasi, dalam pengelolaannya perlu memperhatikan pemanfaatan sumber daya hutan oleh masyarakat yang hidup di dalam dan sekitar kawasannya. Meski pemanfaatan sumber daya hutan berupa pengambilan tumbuhan dan satwa liar di dalam kawasan taman nasional untuk konsumsi terlebih produksi tidak didukung oleh peraturan, namun tidak bisa dipungkiri bahwa praktek pemanfaatan itu berjalan di masyarakat. Adanya data pemanfaatan sumber daya hutan oleh masyarakat desa sekitar kawasan TN Kutai akan menjadi masukan bagi pengelola TN Kutai dalam mengambil langkah-langkah pengelolaan yang lebih baik dan terasa manfaatnya oleh masyarakat sekitar. Sehingga gangguan terhadap kelestarian TN Kutai bisa dihindari. Tujuan penelitian ini adalah (1) Mengetahui pemanfaatan sumber daya hutan oleh masyarakat desa sekitar SPTN Wilayah II, TN Kutai; (2) Mengetahui kontribusi pendapatan dari hasil hutan terhadap pendapatan totalmasyarakat desa sekitar TN Kutai di SPTN Wilayah II.

\section{METODA PENELITIAN}

\subsection{Tempat dan Waktu}

Lokasi penelitian adalah 5 desa di sisi barat TN Kutai pada Seksi Pengelolaan TN Wilayah II yang terdiri dari 2 desa di Kecamatan Muara Kaman, Kabupaten Kutai Kartanegara dan 3 desa di Kecamatan Batu Ampar, Kabupaten Kutai Timur. Desa yang sebagian wilayahnya berada di dalam kawasan TN Kutai adalah Desa Menamang Kanan dan Desa Menamang Kiri. Namun tidak ada pemukiman penduduk kedua desa tersebut di dalam kawasan TN Kutai. Sedangkan Desa Mawai Indah, Desa Beno Harapan dan Desa Himba Lestari wilayahnya di luar kawasan TN Kutai. Pemukiman penduduk di 5 desa tersebut berada dekat dengan kawasan TN Kutai. Pengambilan data dilakukan pada bulan September 2018. 


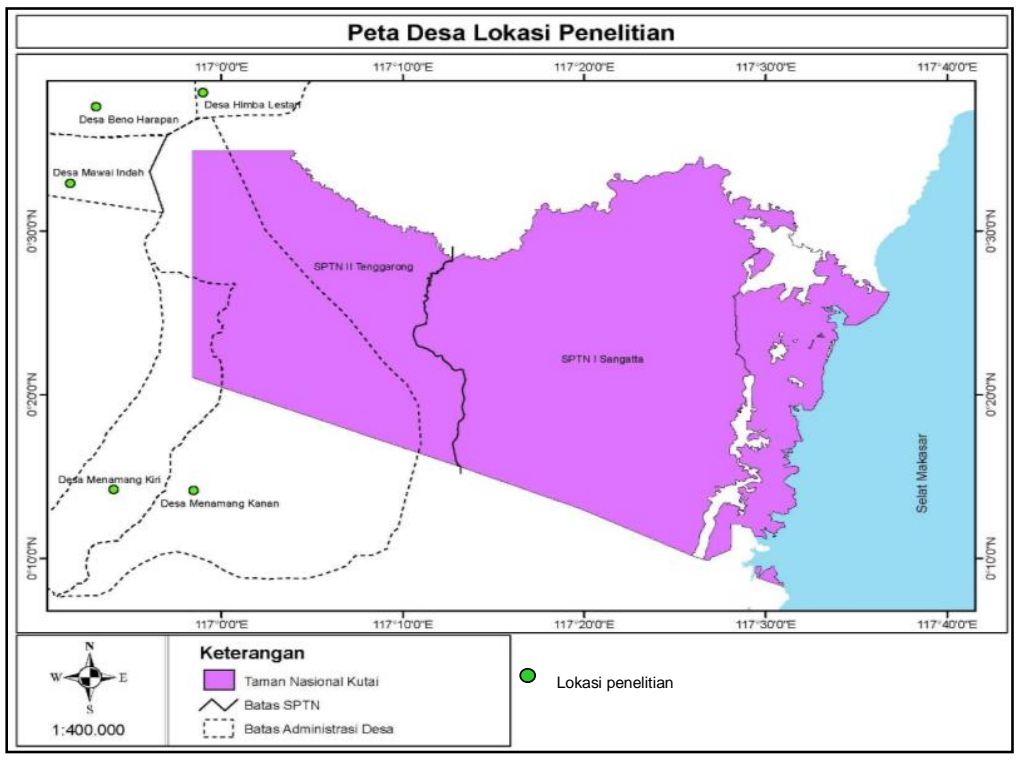

Gambar 2. Peta Desa Lokasi Penelitian

2.2. Bahan dan Alat

Alat dan bahan yang digunakan dalam penelitian ini adalah peta, kuisioner, alat tulis, komputer dan kamera.

\subsection{Metode Pengumpulan Data}

Data yang dikumpulkan dalam penelitian adalah data primer dan data sekunder.Data primer diperoleh dari sumber pertama menggunakan instrumen kuisioner disertai wawancara. Data primer yang diambil yaitu: biodata responden (di antaranya umur, tingkat pendidikan, pekerjaan, pendapatan, jumlah tanggungan keluarga), jenis dan pendapatan sampingan, serta pemanfaatan hasil hutan (jenis, lokasi, jumlah, waktu, pendapatan). Sedangkan data sekunder yang dikumpulkan adalah data sarana prasarana, gambaran umum lokasi penelitian dan data sosial ekonomi. Data sekunder diperoleh dari Balai Taman Nasional Kutai, dari Kantor Desa dan dari sumber lainnya.

Penelitian ini termasuk penelitian eksploratif deskriptif, yaitu meneliti sesuatu yang belum pernah diteliti orang lain atau menemukan sesuatu yang baru. Hasil penelitian deskriptif lebih ditekankan pada pemberian gambaran secara objektif tentang keadaan sebenarnya. Akan tetapi, guna mendapatkan manfaat yang lebih luas, di samping mengungkap fakta diberikan interpretasi yang cukup kuat (Wirartha, 2006).

Metode penentuan responden adalah dengan accidental sampling atau disebut juga incidental sampling atau convenience sampling. Menurut Soehartono (2002) metode ini termasuk dalam non-probability sampling dimana hasil penelitian belum bisa dijadikan landasan generalisasi. Sebagaimana arti dari nama metode ini (accidental/incidental : kebetulan atau convenience : mudah), responden dengan metode ini adalah anggota populasi yang kebetulan ditemukan atau mereka yang mudah ditemui/dijangkau. Metode ini dipilih karena dianggap sesuai dengan keadaan dan situasi desa-desa lokasi penelitian yaitu letak rumah 
penduduk yang tersebar dan minimnya data tentang mata pencaharian rumah tangga.

Tidak ada ketentuan yang pasti berapa sebenarnya ukuran sampel minimum yang dapat dipakai sebagai pedoman (Wirartha, 2006). Untuk jenis penelitian deskriptif sampel minimum adalah $10 \%$ dari populasi (Sumanto, 1990 dalam Wirartha, 2006). Penelitian ini mengambil responden dengan intensitas sampel $10 \%$ dari populasi yang merupakan kepala rumah tangga. Responden adalah kepala rumah tangga yang ditemui secara acak dan sedapat mungkin tersebar di areal pemukiman. Melalui penghitungan intensitas sampel terhadap total rumah tangga tiap desa diperoleh jumlah responden sebagaimana pada Tabel 1. Pendataan pemanfaatan hasil hutan terhadap masyarakat yang bermukim dekat kawasan perlindungan alam perlu pendekatan persuasif sedemikian rupa agar masyarakat tidak merasa dimatamatai.

Tabel 1. Jumlah Populasi dan Sampel Responden Tiap Desa

\begin{tabular}{clcc}
\hline No & Nama Desa & Jumlah Rumah Tangga $(\mathrm{N})$ & Jumlah Responden $(10 \%)$ \\
\hline 1 & Menamang Kanan & $321(*)$ & 33 \\
2 & Menamang Kiri & $138(*)$ & 14 \\
3 & Mawai Indah & $201(* *)$ & 21 \\
4 & Beno Harapan & $217(* *)$ & 22 \\
5 & Himba Lestari & $86(* *)$ & 14 \\
\hline & Jumlah & & 104 \\
\hline
\end{tabular}

Keterangan : (*) sumber data Anonim (2018 ${ }^{\mathrm{a}}$ ) (**) sumber data Anonim (2018 $\left.{ }^{\mathrm{b}}\right)$

Selain responden kepala rumah tangga, data juga diperoleh dari 3 orang informan kunci yang merupakan warga setempat serta narasumber yang merupakan petugas Balai TN Kutai. Informan kunci berperan sebagai pemberi data pendukung terhadap data yang diberikan responden. Narasumber memberikan data pelengkap dan tambahan.

\subsection{Analisis Data}

Data yang dikumpulkan melalui wawancara dan pengisian kuisioner seluruhnya ditabulasi dalam satu tabel. Pengelompokkan dan pengolahan data dilakukan bertahap yang disesuaikan dengan tujuan. Pengolahan data sesuai tujuan penelitian adalah sebagai berikut :
2.4.1. Pengolahan data pemanfaatan sumber daya hutan

Data responden yang memanfaatkan sumber daya hutan di pisahkan dari data lainnya untuk memudahkan pengolahan selanjutnya.Rekapitulasi data responden yang memanfaatkan hasil hutan dicermati dan dikaji kemudian dilakukan pembahasan.

2.42. Pengolahan data pendapatan dari hasil hutan

Penghitungan dilakukan untuk menentukan pendapatan keluarga responden berupa pendapatan pokok, pendapatan sampingan dan pendapatan yang bersumber dari hasil hutan. Pendapatan dalam penelitian ini adalah pendapatan kotor. Persamaan atau rumus yang digunakan dalam penghitungan 
serta urutan penghitungannya mengikuti penelitian oleh Iswandono (2007) yaitu sebagai berikut :

- Menghitung pendapatan keluarga

Langkah pertama menghitung pendapatan keluarga adalah dengan menentukan pendapatan pokok dan pendapatan sampingan. Selanjutnya menghitung pendapatan keluarga yang bersumber dari hasil hutan dengan menggunakan rumus sebagai berikut :

$$
P_{H j}=\sum_{i=1}^{s} V_{H i} \cdot P_{H i}
$$

$\mathrm{V}_{H i}$ adalah rata-rata pengambilan hasil hutan ke i setiap bulan. $\mathrm{P}_{H i}$ adalah nilai harga jual komoditi jenis i. sedangkan $\mathrm{s}$ adalah jumlah jenis yang dimanfaatkan. Pendapatan dari hasil hutan bisa juga merupakan upah dari pekerjaan mengambil hasil hutan.

$$
\text { Apabila sudah diketahui }
$$
pendapatan pokok, pendapatan sampingan dan pendapatan dari hasil hutan setiap keluarga, maka dihitung pendapatan total keluarga dengan menggunakan persamaan sebagai berikut:

$$
P_{j}=P_{P j}+P_{S j}+P_{H j}
$$

$\mathrm{Pj}$ menyatakan total pendapatan keluarga ke-j (Rp/th), Ppj menyatakan pendapatan keluarga ke-j dari sumber pekerjaan pokok (Rp/bulan), Psj menyatakan pendapatan keluarga ke-j dari sumber pekerjaan sampingan (Rp/bulan) dan $\mathrm{PHj}$ menyatakan pendapatan keluarga ke-j dari sumber pemanfaatan hasil hutan.

- Menghitung kontribusi hasil hutan terhadap pendapatan total keluarga

Langkah kedua yaitu menghitung kontribusi atau peran hasil hutan bagi pendapatan setiap keluarga. Rumus yang digunakan sebagai berikut:

$$
K_{H j}=\frac{P_{H j}}{P j} \times 100 \%
$$

$\mathrm{KHj}$ menyatakan kontribusi pendapatan dari hasil hutan bagi pendapatan total keluarga ke-j.

\section{HASIL PENELITIAN DAN PEMBAHASAN}

\subsection{Pemanfaatan Sumber Daya Hutan} oleh Masyarakat Sekitar Kawasan Taman Nasional Kutai SPTN Wilayah II

Kegiatan pemanfaatan ada yang dilakukan responden pada waktu lampau dan sudah tidak dilakukan lagi serta ada yang dilakukan responden saat sekarang (saat penelitian). Sumber daya hutan yang dimanfaatkan terutama tumbuhan berupa pohon atau kayu dan satwa liar. Pemanfaatan sumber daya hutan itu umumnya untuk tujuan keuntungan ekonomi. Data pemanfaatan sumber daya hutan oleh responden di waktu lampau dapat dilihat pada Tabel 2 .

Waktu pemanfaatan terlama adalah tahun 1990, saat itu status TN Kutai adalah merupakan sebagian dari Suaka Margasatwa Kutai yang diusulkan menjadi taman nasional seluas 200.000 ha. Masyarakat sekitar mengenalnya sebagai hutan lindung. Sejak 29 Juni 1995 baru terjadi penunjukkan kawasan sebagai Taman Nasional Kutai. Saat ini (saat penelitian) pekerjaan responden yang pernah memanfaatkan hasil hutan di masa lampau adalah menjadi petani/pekebun, karyawan swasta, perangkat desa dan PNS. Sumber pendapatan mereka sekarang lebih pasti dan teratur, karena itu kegiatan pemanfaatan hasil hutan sudah tidak lagi mereka lakukan. 
Tabel 2 Pemanfaatan Sumber Daya Hutan oleh Responden di Waktu Lampau

\begin{tabular}{|c|c|c|c|c|c|}
\hline \multirow[b]{2}{*}{ Kriteria } & \multicolumn{5}{|c|}{ Desa } \\
\hline & $\begin{array}{c}\text { Menamang } \\
\text { Kanan }\end{array}$ & Menamang Kiri & Mawai Indah & $\begin{array}{c}\text { Beno } \\
\text { Harapan }\end{array}$ & $\begin{array}{l}\text { Himba } \\
\text { Lestari }\end{array}$ \\
\hline Jumlah Responden & 33 & 14 & 21 & 22 & 14 \\
\hline $\begin{array}{l}\text { Jumlah responden yang } \\
\text { pernah memanfaatkan } \\
\text { hasil hutan }\end{array}$ & 5 & 14 & 1 & 1 & 2 \\
\hline Tahun Pemanfaatan & $1990-2007$ & $1990-2007$ & Sebelum1993 & 2003 & $\begin{array}{c}\text { sebelum } \\
2014\end{array}$ \\
\hline Lokasi & $\begin{array}{l}\text { Sungai } \\
\text { Menamang, } \\
\text { TNK }\end{array}$ & $\begin{array}{l}\text { TNK, Sungai } \\
\text { Menamang, } \\
\text { Sungai Mau }\end{array}$ & Eks Kiani & HTI & $\begin{array}{c}\text { Pos } 2, \text { HTI, } \\
\text { sepanjang } \\
\text { jalan }\end{array}$ \\
\hline \multicolumn{6}{|c|}{ Jenis hasil hutan yang dimanfaatkan } \\
\hline Tumbuhan & $\begin{array}{l}\text { Ulin, rotan, } \\
\text { meranti, } \\
\text { bayur, tunjuk } \\
\text { langit }\end{array}$ & $\begin{array}{l}\text { Ulin, meranti, } \\
\text { pipi, rotan, } \\
\text { kayu gembor, } \\
\text { gaharu, ulin } \\
\text { sirap, kayu } \\
\text { putih }\end{array}$ & $\begin{array}{c}\text { Damar, } \\
\text { gaharu, rotan }\end{array}$ & $\begin{array}{l}\text { Ulin, } \\
\text { meranti }\end{array}$ & $\begin{array}{l}\text { Ulin, } \\
\text { meranti, } \\
\text { rotan besar }\end{array}$ \\
\hline Satwa & $\begin{array}{l}\text { Payau, babi, } \\
\text { burung, ikan }\end{array}$ & $\begin{array}{l}\text { Ikan, krentia, } \\
\text { lawi }\end{array}$ & & & \\
\hline Lainnya & Sarang walet & & & & \\
\hline
\end{tabular}

Memperhatikan pemanfaatan hasil hutan berupa sarang walet di masa lampau yang terdapat di goa-goa, maka dapat dikatakan cukup banyak goa-goa di dalam kawasan TN Kutai. Goa-goa bisa menjadi objek wisata yang potensial dikembangkan dan bisa menjadi sumber penghasilan bagi masyarakat sekitar. Letak dan kondisi goa-goa itu perlu diketahui lebih lanjut dengan menggali informasi dari responden yang melakukan pengambilan sarang walet di masa lampau tersebut.

Tabel 3. Pemanfaatan Sumberdaya Hutan oleh Responden di Waktu Sekarang (September 2018)

\begin{tabular}{|c|c|c|c|c|c|}
\hline \multirow[b]{2}{*}{ Kriteria } & \multicolumn{5}{|c|}{ Desa } \\
\hline & $\begin{array}{l}\text { Menamang } \\
\text { Kanan }\end{array}$ & $\begin{array}{l}\text { Menamang } \\
\text { Kiri }\end{array}$ & Mawai Indah & $\begin{array}{c}\text { Beno } \\
\text { Harapan }\end{array}$ & $\begin{array}{l}\text { Himba } \\
\text { Lestari }\end{array}$ \\
\hline Jumlah Responden & 33 & 14 & 21 & 22 & 14 \\
\hline $\begin{array}{l}\text { Jumlah responden yang } \\
\text { memanfaatkan hasil hutan } \\
\text { saat ini }\end{array}$ & 2 & - & 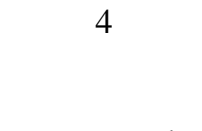 & 6 & 11 \\
\hline $\begin{array}{l}\text { Lokasi pengambilan hasil } \\
\text { hutan }\end{array}$ & Petak 100 & - & $\begin{array}{c}\text { HTI, areal } \\
\text { PHK, Petak } \\
100\end{array}$ & $\begin{array}{l}\text { PT. MPS, } \\
\text { limbah HTI }\end{array}$ & $\begin{array}{l}\text { Pos 2, Plang } \\
\text { Payau, } \\
\text { DPNJ, eks } \\
\text { Kiani }\end{array}$ \\
\hline \multicolumn{6}{|c|}{ Jenis hasil hutan yang dimanfaatkan } \\
\hline Tumbuhan & Ulin & - & $\begin{array}{l}\text { Ulin, kapur, } \\
\text { meranti, } \\
\text { rotan }\end{array}$ & $\begin{array}{l}\text { Ulin, } \\
\text { meranti, } \\
\text { kapur }\end{array}$ & $\begin{array}{l}\text { Ulin, } \\
\text { meranti, } \\
\text { kapur }\end{array}$ \\
\hline Satwa & $\begin{array}{c}\text { Payau, } \\
\text { kijang kancil }\end{array}$ & - & & & $\begin{array}{c}\text { payau, } \\
\text { kijang kancil }\end{array}$ \\
\hline
\end{tabular}


Selain adanya responden yang memanfaatkan hasil hutan di waktu lampau, hasil penelitian juga mendapatkan data responden yang melakukan pemanfaatan hasil hutan di waktu sekarang (September 2018). Data pemanfaatan sumber daya hutan oleh responden di waktu sekarang dapat dilihat pada Tabel 3.

Data di desa Menamang Kanan terdapat 2 responden yang saat ini melakukan pengambilan hasil hutan. Jenis yang diambil adalah kayu/pohon jenis ulin, meranti dan jenis komersil lainnya dan satwa jenis payau/rusa sambar. Penggunaannya adalah untuk keperluan sendiri dan juga dijual. Penjualan di sekitar Desa Menamang Kanan hingga ke Desa Sebulu.

Responden pada Desa Mawai Indah terdapat 4 responden yang melakukan pemanfaatan hasil hutan saat sekarang. Jenis yang dimanfaatkan yaitu kayu jenis ulin dan meranti. Hasil dari hutan adalah sebagai penghasilan/pekerjaan utama.

Pemanfaatan sumber daya hutan di Desa Beno Harapan dilakukan oleh 6 responden. Jenis yang dimanfaatkan berupa kayu jenis ulin dan meranti. Jenis satwa yang dimanfaatkan yaitu payau dan kanci. Penggunaannya yaitu sebagian untuk sendiri dan sebagian besar dijual. Harga jual kayu berkisar antara 2 juta/m3. Sedangkan payau dijual dengan harga rata-rata Rp75.000 per kg.

Desa Himba Lestari menunjukkan jumlah responden yang paling banyak memanfaatkan sumber daya hutan. Dari 14 responden terdapat 2 yang pernah melakukan di masa lampau dan 11 responden yang melakukannya saat sekarang. Jenis hasil hutan berupa pohon/kayu ulin dan meranti, burung parkit, payau, kancil, babi. Sebagian besar merupakan pekerjaan atau sumber penghasilan utama.
Sumber daya hutan yang bisa dimanfaatkan cukup banyak jenisnya. Secara garis besar bisa terbagi menjadi 2 jenis yaitu 1) kondisi lingkungan dan 2) tumbuhan dan satwa liar (TSL). Menurut PP 28/2011 Pasal 1, kondisi lingkungan hutan yang bisa dimanfaatkan antara lain pemanfaatan potensi ekosistem, keadaan iklim, fenomena alam, kekhasan jenis dan peninggalan budaya yang berada dalam taman nasional. Namun semua jenis hasil hutan yang dimanfaatkan responden saat ini adalah merupakan tumbuhan dan satwa liar (TSL). Bentuknya berupa pengambilan dan perdagangan TSL yaitu kayu (ulin, meranti, kapur), payau/rusa, kijang dan kancil. Tidak ditemukan responden yang memanfaatkan sumber daya berupa kondisi lingkungan hutan. Padahal pengambilan dan perdagangan TSL dari dalam kawasan taman nasional tidak diperbolehkan.

Pemanfaatan yang bisa dilakukan di taman nasional antara lain dalam bentuk: penelitian dan pengembangan ilmu pengetahuan; pendidikan dan peningkatan kesadartahuan konservasi alam; penyimpanan dan/atau penyerapan karbon, pemanfaatan air, energi air, panas, angin, dan wisata alam; tumbuhan dan satwa liar; sumber plasma nutfah untuk penunjang budi daya (PP. 28/2011 Pasal 35). Sedangkan pemanfaatan jenis TSL yang boleh dilakukan di dalam kawasan taman nasional adalah dalam bentuk: pengkajian, penelitian dan pengembangan; penangkaran; perburuan; perdagangan; peragaan; pertukaran; budidaya tanaman obat-obatan; dan pemeliharaan untuk kesenangan (PP. 8/1999 Pasal 3). Namun UU No. 5/1990 Pasal 27 dan 28 mengatur bahwa pemanfaatan kondisi lingkungan dilakukan dengan tetap menjaga kelestarian fungsi kawasan, sementara pemanfaatan jenis TSL dilakukan dengan 
memperhatikan kelangsungan potensi, daya dukung, dan keanekaragaman jenis tumbuhan dan satwa liar. Sedangkan PP No. 28/2011 Pasal 38 membatasi lagi pemanfaatan di taman nasional hanya dapat dilakukan setelah memperoleh izin dari menteri atau pejabat yang ditunjuk.

Semua jenis hasil hutan yang dimanfaatkan responden saat ini adalah merupakan tumbuhan dan satwa liar (TSL) yang bernilai ekonomis tinggi. Kayu ulin dan meranti adalah bahan bangunan utama rumah-rumah di pemukiman. Kebutuhan akan kayu selalu tinggi. Harganya pun sangat tinggi maka memberikan keuntungan yang besar bagi para pengusahanya. Demikian pula dengan satwa liar buruan, harga satwa buruan seperti payau juga sangat tinggi dan tingkat permintaan juga selalu tinggi. Kebutuhan sumber protein juga tinggi. Peternakan dan perikanan di desa-desa lokasi penelitian belum maju dan memilki banyak kendala serta tantangan. Mengambil satwa liar dari hutan tidak memerlukan modal dan usaha yang besar sehingga menjadi potensi yang sangat menguntungkan untuk diperdagangkan.

Latar belakang responden yang memanfaatkan hasil hutan yaitu belum memiliki pekerjaan tetap sebagai sumber pendapatan utama. Ada pula yang baru memulai usaha perkebunan pada usia tanam yang masih sangat muda sehingga belum menghasilkan. Selain itu kondisi harga komoditi pertanian dan perkebunan yang merupakan sumber pendapatan utama masyarakat sedang berada pada titik rendah bahkan sangat rendah, sehingga dirasa perlu mencari alternatif sumber pendapatan.

Jenis aktivitas dalam pemanfaatan hasil hutan yang diketahui dari penelitian ini adalah penebangan pohon, pengangkutan kayu, perburuan/penjeratan satwa dan perdagangan (kayu dan satwa). Pendapatan dari hasil hutan berupa keuntungan dari perdagangan/penjualan hasil hutan dan juga upah sebagai tenaga kerja pada kegiatan pengambilan hasil hutan.

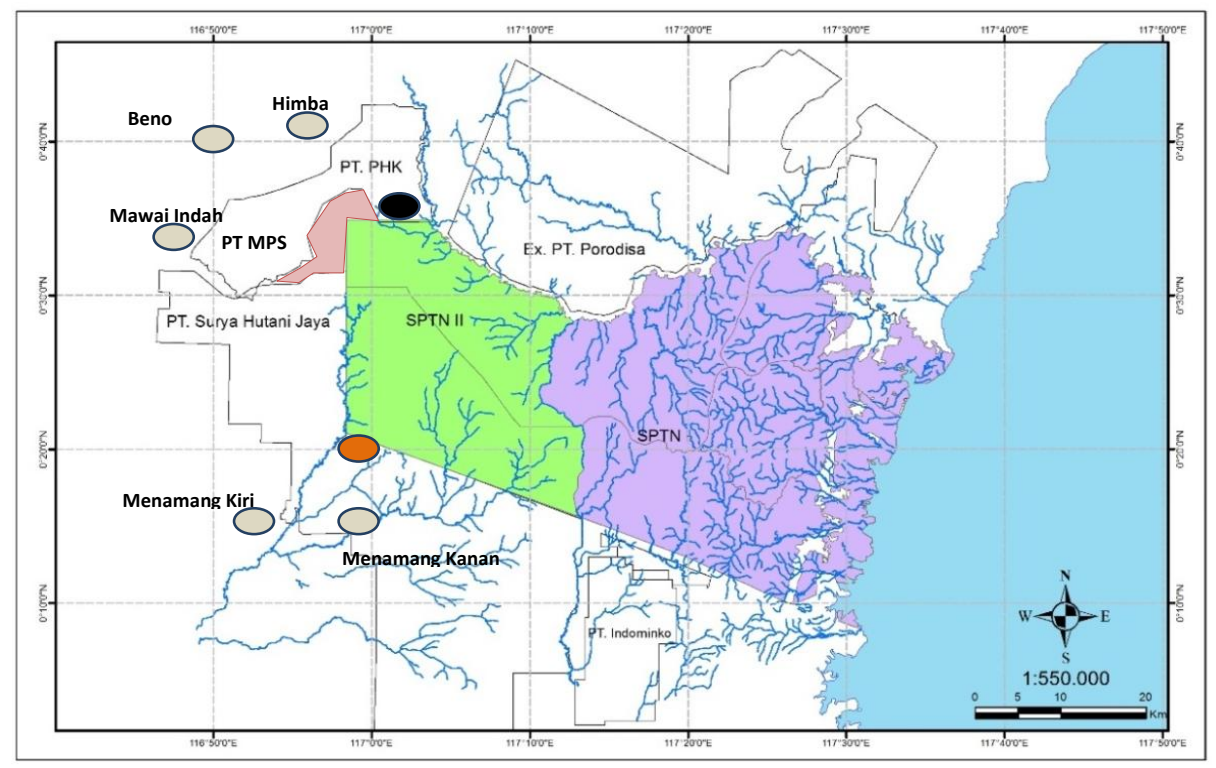

Gambar 3. Peta Lokasi Pengambilan Hasil Hutan

Hasil wawancara mendapatkan data bahwa responden yang memanfaatkan hasil hutan di masa lampau menyebutkan lokasi pengambilan adalah di dalam kawasan TN Kutai. Sedangkan lokasi pengambilan hasil hutan yang dilakukan 
saat ini dijelaskan responden adalah di lokasi-lokasi yang disebut dengan nama Petak 100, DPNJ, Plang Payau, Pos 2, PT MPS, Eks Kiani dan Eks HTI. Lokasilokasi tersebut kesemuanya mengarah ke kawasan TN Kutai. Letak lokasi pengambilan hasil hutan yang disebutkan responden adalah sebagaimana pada Gambar 3.

Batas barat kawasan TN Kutai hampir seluruhnya bersentuhan dengan batas konsesi HTI. Hanya bagian berwarna merah muda yang bukan areal konsesi dan merupakan wilayah Desa Menamang Kanan. Berdasarkan penjelasan petugas Balai TN Kutai SPTN Wilayah II, kawasan tersebut merupakan hutan yang ditumbuhi pohon kayu ulin dan meranti yang jumlahnya tidak banyak serta ukuran yang tidak besar. Sedangkan di bagian lain batas kawasan terdapat areal penyangga dengan lebar antara 500$1.000 \mathrm{~m}$. Areal itu merupakan kawasan bekas hutan yang kondisinya sekarang ditumbuhi pohon-pohon pionir, semaksemak dan padang rumput.

Meskipun secara eksplisit tidak ada reponden yang menyebutkan lokasi pengambilan hasil hutan saat ini adalah di dalam kawasan TN Kutai, namun dengan memperhatikan bahwa terdapat jalan/akses dari titik-titik lokasi yang disebutkan responden menembus hingga ke dalam kawasan TN Kutai, maka perlu dikhawatirkan bahwa hasil hutan yang diambil ada juga yang berasal dari dalam kawasan TN Kutai. Selain itu kondisi areal penyangga yang miskin potensi tentu sulit mendapatkan hasil hutan bernilai ekonomi yang bisa diambil. Rahmat (2007) dalam penelitiannya yang berlokasi di desa penyangga Taman Nasional Kerinci Seblat mengungkapkan bahwa salah satu pendapatan hutan pada masyarakat desa penyangga diantaranya adalah hasil kayu dari kegiatan illegal logging.

Tabel 4. Distribusi Responden Menurut Sumber dan Besar Pendapatan Pokok

\begin{tabular}{|c|c|c|c|c|c|}
\hline \multirow{2}{*}{$\begin{array}{c}\text { Sumber Pendapatan } \\
\text { Pokok }\end{array}$} & \multicolumn{5}{|c|}{ Desa } \\
\hline & $\begin{array}{c}\text { Menamang } \\
\text { Kanan }\end{array}$ & $\begin{array}{c}\text { Menamang } \\
\text { Kiri }\end{array}$ & $\begin{array}{c}\text { Mawai } \\
\text { Indah }\end{array}$ & $\begin{array}{c}\text { Beno } \\
\text { Harapan }\end{array}$ & $\begin{array}{l}\text { Himba } \\
\text { Lestari }\end{array}$ \\
\hline Petani/pekebun & 12 & 2 & 16 & 12 & 5 \\
\hline Wiraswasta & 2 & - & - & 2 & - \\
\hline $\begin{array}{l}\text { Karyawan/tenaga } \\
\text { harian/upah }\end{array}$ & 17 & 8 & - & 3 & - \\
\hline PNS/perangkat desa & 1 & 4 & 4 & 5 & - \\
\hline Hasil hutan & 1 & & 1 & & 9 \\
\hline Jumlah & 33 & 14 & 21 & 22 & 14 \\
\hline $\begin{array}{l}\text { Total pendapatan pokok } \\
\text { per bulan }(\mathrm{Rp})\end{array}$ & 94.350 .000 & 37.509 .000 & 71.325 .000 & 47.957 .000 & 45.400 .000 \\
\hline $\begin{array}{l}\text { Rata-rata Pendapatan } \\
\text { Pokok per bulan (Rp) }\end{array}$ & 2.859 .091 & 2.679 .214 & 3.396 .429 & 2.179 .864 & 3.242 .857 \\
\hline
\end{tabular}

\subsection{Pendapatan Masyarakat}

Pendapatan masyarakat/responden diperoleh dari menganalisis sumbersumber pendapatan sehingga diketahui semua sumber pendapatan yang dikelompokkan menjadi pendapatan utama/pokok, pendapatan sampingan dan pendapatan dari hasil hutan. Kemudian dihitung pendapatan dari masing-masing sumber tersebut. Hasil analisis dan 
penghitungan pendapatan pokok responden disajikan pada Tabel 4. Sedangkan hasil analisis dan penghitungan pendapatan sampingan responden disajikan pada Tabel 5 . Kemudian hasil analisis dan penghitungan pendapatan responden dari hasil hutan disajikan pada Tabel 6.

Pendapatan pokok responden di Desa Menamang Kanan dan Desa Menamang Kiri sebagian besar bersumber dari pekerjaan sebagai karyawan. Responden di Desa Mawai Indah dan Desa Beno Harapan sebagian besar adalah petani/pekebun. Sedangkan responden di Desa Himba Lestari sebagian besar pekerjaan pokoknya adalah dari hasil hutan yaitu sebagai tenaga tebang dan angkut serta penjual.

Rata-rata pendapatan pokok sebagaimana pada Tabel 4 menunjukkan angka tertinggi terdapat pada responden di Desa Mawai Indah yaitu sebesar Rp3.396.429,-. Sedangkan yang terendah adalah pendapatan pokok rata-rata responden di Desa Beno Harapan sebesar Rp2.179.864,- per bulan. Namun data rata-rata pendapatan dari penghasilan sampingan (Tabel 5) di Desa Beno Harapan menunjukkan nilai yang cukup besar yaitu Rp3.192.500,-.

Tabel 5. Distribusi Responden Menurut Sumber dan Besar Pendapatan Sampingan

\begin{tabular}{|c|c|c|c|c|c|}
\hline \multirow{2}{*}{$\begin{array}{c}\text { Sumber pendapatan } \\
\text { sampingan }\end{array}$} & \multicolumn{5}{|c|}{ Desa } \\
\hline & $\begin{array}{c}\text { Menamang } \\
\text { Kanan }\end{array}$ & $\begin{array}{c}\text { Menamang } \\
\text { Kiri }\end{array}$ & Mawai Indah & $\begin{array}{c}\text { Beno } \\
\text { Harapan }\end{array}$ & $\begin{array}{l}\text { Himba } \\
\text { Lestari }\end{array}$ \\
\hline Perkebunan & 6 & 13 & 2 & 6 & - \\
\hline Perdagangan & 2 & - & 3 & 2 & 1 \\
\hline Jasa & 1 & - & 1 & - & - \\
\hline Budidaya & 4 & - & - & - & - \\
\hline Peternakan & 1 & - & - & - & - \\
\hline Hasil hutan & 1 & - & 3 & 6 & 2 \\
\hline Lainnya & 1 & - & 1 & 2 & - \\
\hline Jumlah & 16 & 13 & 10 & 16 & 3 \\
\hline $\begin{array}{l}\text { Total pendapatan } \\
\text { sampingan (Rp) }\end{array}$ & 42.770 .000 & 20.500 .000 & 35.500 .000 & 51.080 .000 & 7.000 .000 \\
\hline $\begin{array}{l}\text { Rata-rata Pendapatan } \\
\text { sampingan per bulan (Rp) }\end{array}$ & 2.673 .125 & 1.576 .923 & 3.550 .000 & 3.192 .500 & 2.333 .333 \\
\hline
\end{tabular}

Data pada Tabel 5 menunjukkan pendapatan sampingan rata-rata tertinggi ternyata juga terdapat pada responden Desa Mawai Indah dengan nilai Rp3.550.000,-. Sedangkan pendapatan sampingan rata-rata paling rendah terdapat di Desa Menamang Kiri. Pendapatan sampingan responden ada yang lebih dari satu sumber. 
Tabel 6. Jumlah Responden dan Besar Pendapatan dari Hasil Hutan

\begin{tabular}{lccccc}
\hline \multirow{2}{*}{ Sumber pendapatan } & \multicolumn{5}{c}{ Desa } \\
\cline { 2 - 6 } & $\begin{array}{c}\text { Menamang } \\
\text { Kanan }\end{array}$ & $\begin{array}{c}\text { Menamang } \\
\text { Kiri }\end{array}$ & $\begin{array}{c}\text { Mawai } \\
\text { Indah }\end{array}$ & $\begin{array}{c}\text { Beno } \\
\text { Harapan }\end{array}$ & $\begin{array}{c}\text { Himba } \\
\text { Lestari }\end{array}$ \\
\hline $\begin{array}{l}\text { Hasil hutan } \\
\text { Total pendapatan dari } \\
\text { hasil hutan (Rp) }\end{array}$ & 2 & 0 & 4 & 6 & 11 \\
\hline
\end{tabular}

Pendapatan responden dari hasil hutan sebagaimana ditampilkan pada Tabel 6 memperlihatkan bahwa pengambil manfaat dari hasil hutan terbanyak adalah di Desa Himba Lestari sekaligus juga menunjukkan nilai pendapatan terbesar dari pemanfaatan hasil hutan. Pendapatan total responden apabila dibuat klasifikasi maka terlihat sebaran jumlah responden sebagaimana pada Tabel 7.

Tabel 7. Distribusi Responden Menurut Kelas Pendapatan Total

\begin{tabular}{lccccc}
\hline $\begin{array}{c}\text { Pendapatan total per } \\
\text { bulan (Rp) }\end{array}$ & $\begin{array}{c}\text { Menamang } \\
\text { Kanan }\end{array}$ & $\begin{array}{c}\text { Menamang } \\
\text { Kiri }\end{array}$ & Mawai Indah & $\begin{array}{c}\text { Beno } \\
\text { Harapan }\end{array}$ & Himba Lestari \\
\hline$<1.000 .000$ & 1 & - & 1 & 3 & - \\
$\begin{array}{l}1.000 .000- \\
<5.000 .000\end{array}$ & 18 & 10 & 11 & 12 & 11 \\
$\begin{array}{l}5.000 .000- \\
<10.000 .000\end{array}$ & 14 & 4 & 6 & 6 & 3 \\
$>10.000 .000$ & - & - & 3 & 1 & - \\
\hline $\begin{array}{l}\text { Jumlah } \\
\text { Pendapatan rata-rata }\end{array}$ & 4.155 .152 & 4.143 .500 & 5.086 .905 & 4.501 .682 & 3.742 .857 \\
\hline Rp)
\end{tabular}

Data pada Tabel 7 menunjukkan bahwa responden pada semua desa lokasi penelitian paling banyak yang memiliki pendapatan total antara 1 juta rupiah hingga 5 juta rupiah. Selain itu juga cukup banyak responden yang memiliki pendapatan total antara 5 juta rupiah hingga 10 juta rupiah. Rata-rata penghasilan total tertinggi terdapat pada responden di Desa Mawai Indah. Sedangkan rata-rata penghasilan total paling rendah terdapat di Desa Himba Lestari.
Rekapitulasi responden dengan pendapatan dari hasil hutan saat sekarang (September 2018) dapat dilihat pada Tabel 8. Rekapitulasi sebagaimana pada Tabel 8 menunjukkan distribusi responden yang memiliki pendapatan dari hasil hutan, baik sebagai sampingan maupun sebagai penghasilan utama/pokok. Responden yang memanfaatkan hasil hutan di Desa Himba Lestari sebagian besar adalah sebagai sumber pendapatan pokok. 
Tabel 8. Rekapitulasi Responden dengan Pendapatan dari Hasil Hutan Saat Sekarang (September 2018)

\begin{tabular}{|c|c|c|c|c|c|}
\hline \multirow[b]{2}{*}{ Karakteristik } & \multicolumn{5}{|c|}{ Desa } \\
\hline & $\begin{array}{c}\text { Menamang } \\
\text { Kanan }\end{array}$ & $\begin{array}{c}\text { Menamang } \\
\text { Kiri }\end{array}$ & $\begin{array}{c}\text { Mawai } \\
\text { Indah }\end{array}$ & $\begin{array}{c}\text { Beno } \\
\text { Harapan } \\
\end{array}$ & $\begin{array}{l}\text { Himba } \\
\text { Lestari }\end{array}$ \\
\hline $\begin{array}{l}\text { Responden yang } \\
\text { pendapatan dari hutan } \\
\text { sebagai penghasilan } \\
\text { pokok }\end{array}$ & 1 & 0 & 1 & 0 & 9 \\
\hline $\begin{array}{l}\text { Responden yang } \\
\text { pendapatan dari hutan } \\
\text { sebagai pendapatan } \\
\text { sampingan }\end{array}$ & 1 & 0 & 3 & 6 & 2 \\
\hline $\begin{array}{l}\text { Responden yang } \\
\text { mempunyai pendapatan } \\
\text { dari hasil hutan }\end{array}$ & 2 & 0 & 4 & 6 & 11 \\
\hline
\end{tabular}

Hasil analisis dan penghitungan mendapatkan data sebagaimana disajikan pada Tabel 9, bahwa kontribusi pendapatan dari hasil hutan terhadap pendapatan total responden tertinggi adalah pada pendapatan responden di Desa Himba Lestari yaitu sebesar 70,04\% (berkisar antara $64,29 \%$ - $100 \%$ per responden dengan pendapatan dari hasil hutan). Desa Beno Harapan di urutan selanjutnya yaitu $26,81 \%$ pendapatan masyarakatnya bersumber dari hasil hutan (berkisar antara 41,86\% - 93,75\% per responden dengan pendapatan dari hasil hutan). Responden pada Desa Mawai Indah memperoleh pendapatan dari hasil hutan sebesar 25,27\% (berkisar antara $54,55 \%$ - 90,91\% per responden dengan pendapatan dari hasil hutan) dan Desa Menamang Kanan paling rendah yaitu 4,89\% (berkisar antara 41,18\% $100 \%$ per responden dengan pendapatan dari hasil hutan). Sedangkan responden di Desa Menamang Kiri tidak ada pendapatan dari hasil hasil hutan.

Tabel 9. Rekapitulasi Pendapatan Responden dan Kontribusi Pendapatan dari Hasil Hutan terhadap Pendapatan Masyarakat

\begin{tabular}{lccccc}
\hline \multicolumn{1}{c}{ Karakteristik } & \multicolumn{5}{c}{ Desa } \\
\cline { 2 - 6 } & $\begin{array}{c}\text { Menamang } \\
\text { Kanan }\end{array}$ & $\begin{array}{c}\text { Menamang } \\
\text { Kiri }\end{array}$ & Mawai Indah & $\begin{array}{c}\text { Beno } \\
\text { Harapan }\end{array}$ & $\begin{array}{c}\text { Himba } \\
\text { Lestari }\end{array}$ \\
\hline $\begin{array}{l}\text { Total pendapatan pokok hutan } \\
\text { dan non hutan (PP) (Rp) }\end{array}$ & 94.350 .000 & 37.509 .000 & 71.325 .000 & 47.957 .000 & 45.400 .000 \\
$\begin{array}{l}\text { Total pendapatan sampingan } \\
\text { hutan dan non hutan (PS) (Rp) } \\
\begin{array}{l}\text { Total pendapatan (P=PP+PS) } \\
\text { (Rp) }\end{array}\end{array}$ & 42.770 .000 & 20.500 .000 & 35.500 .000 & 51.080 .000 & 7.000 .000 \\
$\begin{array}{l}\text { Total pendapatan dari hasil } \\
\text { hutan (PH) (Rp) }\end{array}$ & 137.120 .000 & 58.009 .000 & 106.825 .000 & 99.037 .000 & 52.400 .000 \\
$\begin{array}{l}\text { Kontribusi hasil hutan terhadap } \\
\text { pendapatan total seluruh }\end{array}$ & 6.700 .000 & - & 27.000 .000 & 26.550 .000 & 36.700 .000 \\
responden & $4,89 \%$ & & & & \\
\end{tabular}


Kondisi harga komoditi saat penelitian adalah berada pada titik sangat rendah. Harga lada rata-rata Rp40.000,per $\mathrm{kg}$, harga karet rata-rata Rp5.000,per $\mathrm{kg}$ dan harga sawit rata-rata hanya Rp500,- per kg. Harga lada pernah berada pada kisaran Rp150.000,- pada sekitar tahun 2015-2016. Namun kemudian harga lada menurun hingga harga yang sekarang ini sudah berlangsung cukup lama tidak mengalami kenaikan.

Kontribusi hasil hutan tertinggi adalah pada responden di Desa Himba Lestari yaitu sebesar 70,04\%. Jumlah responden yang mempunyai pendapatan dari hasil hutan memang tertinggi di desa ini. Namun jika diperhatikan data lainnya bahwa responden yang mengambil hasil hutan sebenarnya juga memiliki lahan pertanian dan perkebunan minimal 2 ha namun belum menghasilkan karena baru ditanam. Ketergantungan terhadap hutan dimungkinkan berkurang apabila hasil perkebunan masyarakat telah memberikan hasil dan juga apabila hargaharga komoditi meningkat lagi.

Kadir (2012) dalam hasil penelitiannya menyatakan bahwa tingkat ketergantungan secara ekonomi masyarakat sekitar terhadap kawasan TN Bantimurung Bulusaraung di Sulawesi Selatan berkisar antara 0,64\% - 100\%, dengan rata-rata tingkat ketergantungan terhadap TN Babul sebesar 37,97\%. Penelitian lain di Malinau menunjukkan bahwa hasil hutan non kayu memberikan kontribusi sebesar 25-93\% kebutuhan masyarakat Malinau yang tinggal di sekitar kawasan hutan. Masyarakat Long Adui memiliki ketergantungan terhadap hasil hutan non kayu sangat tinggi, karena sebagian besar masyarakat di desa ini melakukan kegiatan ekstraktivisme hasil hutan non kayu untuk memenuhi kebutuhan hidup rumah tangganya (Munawaroh, 2011).
Ketergantungan responden terhadap hasil hutan paling rendah adalah di Desa Menamang Kiri yaitu 0\% dan tertinggi di Desa Himba Lestari sebesar 70,04\%. Penelitian di Taman Nasional Gunung Halimun Salak (TNGHS) oleh Adalina (2017) menyebutkan bahwa selain memanfaatkan HHBK responden juga memanfaatkan jenis kayu-kayuan yang ditanam di lahan garapan di kawasan TNGHS. Secara umum interaksi masyarakat dengan hutan tidak terlepas dari kegiatan negatif (illegal). Secara dejure penebangan kayu di lahan garapan di kawasan TNGHS dilarang. Penggunaan lahan TNGHS memberikan kontribusi sebesar $42,29 \%$ terhadap total pendapatan rumah tangga responden. Sumber daya TNGHS merupakan tumpuan hidup bagi masyarakat Kasepuhan dalam memenuhi kebutuhan hidupnya.

\section{KESIMPULAN}

Pemanfaatan sumber daya hutan oleh masyarakat di lokasi penelitian adalah berupa pengambilan jenis tumbuhan dan satwa liar terutama kayu bernilai ekonomis tinggi seperti ulin, meranti dan kapur. Satwa yang dimanfaatkan adalah terutama payau, selain itu adalah kijang dan kancil. Masyarakat yang mengambil hasil hutan di waktu lampau menyebutkan dengan jelas bahwa dahulu mereka mengambilnya di dalam TN Kutai. Sedangkan masyarakat yang mengambil hasil hutan di saat sekarang menyebutkan lokasi pengambilan hasil hutan pada tempat-tempat yang sangat dekat dengan kawasan TN Kutai sehingga patut dikhawatirkan bahwa aktivitas mereka mengancam kelestarian kawasan TN Kutai. 
Pendapatan masyarakat dari hasil hutan, baik sebagai penghasilan pokok maupun sebagai penghasilan sampingan, terbanyak adalah di Desa Himba Lestari dengan jumlah responden 11 orang, total pendapatan seluruh responden per bulan dari hasil hutan sebesar Rp36.700.000,dan kontribusi hasil hutan terhadap pendapatan masyarakat sebesar 70,04\%. Selanjutnya secara berurutan hingga yang terkecil adalah Desa Beno Harapan dengan jumlah responden 6 orang, total pendapatan responden per bulan dari hasil hutan sebesar Rp26.550.000,- dan kontribusi hasil hutan terhadap pendapatan masyarakat sebesar 26,81\%. Desa Mawai Indah dengan jumlah responden 4 orang, total pendapatan responden per bulan dari hasil hutan sebesar Rp27.000.000,- dan kontribusi hasil hutan terhadap pendapatan masyarakat sebesar 26,27\%, terakhir Desa Menamang Kanan dengan jumlah responden 2 orang, total pendapatan responden per bulan dari hasil hutan sebesar Rp6.700.000,- dan kontribusi hasil hutan terhadap pendapatan masyarakat sebesar 4,89\%. Sedangkan Desa Menamang Kiri tidak ada responden yang sumber pendapatannya dari hasil hutan. Perlu perhatian dan pengawasan tinggi terhadap masyarakat desa sekitar TN Kutai terutama desa dengan pelaku pemanfaatan hasil hutan tertinggi. Selain itu juga perlu diusahakan meningkatkan pendapatan masyarakat dari kegiatan perekonomian yang mandiri dan tidak tergantung pada kawasan hutan yang dilindungi.

\section{DAFTAR PUSTAKA}

Adalina, Y. 2017. Pemanfaatan hasil hutan bukan kayu di Taman Nasional Gunung Halimun Salak oleh Masyarakat Kasepuhan Sinar Resmi, Jawa Barat. Proseeding
Seminar Nasional Masyarakat Biodivversitas Indonesia 3 (1): 75 -80 .

Anonim. 1990. Undang-Undang RI No 5 tahun 1990 tentang Konservasi Sumber Daya Alam Hayati dan Ekosistemnya. Departemen Kehutanan. Jakarta.

Anonim. 1999. Undang-undang RI Nomor 41 Tahun 1999 tentang Kehutanan. Departemen Kehutanan. Jakarta.

Anonim. 2011. Peraturan Pemerintah Republik Indonesia Nomor 28 Tahun 2011 tentang Pengelolaan Kawasan Suaka Alam dan Kawasan Pelestarian Alam.Presiden Indonesia. Jakarta.

Anonim. 2017. Rencana Pengelolaan Jangka Panjang Provinsi Kalimantan Timur Taman Nasional Kutai Periode 2018 - 2027. Balai Taman Nasional Kutai. Bontang.

Anonim. 2018 ${ }^{\mathrm{a}}$. Kabupaten Kutai Kartanegara dalam Angka. Badan Pusat Statistik Kabupaten Kutai Kartanegara. $271 \mathrm{~h}$.

Anonim. 2018 ${ }^{\mathrm{b}}$. Kabupaten Kutai Timur dalam Angka. Badan Pusat Statistik Kabupaten Kutai Timur. 271 h.

Bismark, M., R. Sawitri, Eman. 2007. Pengelolaan dan Zonasi Daerah Penyangga Taman Nasional Gunung Ciremai, Kabupaten Kuningan, Jawa Barat. Jurnal Penelitian Hutan dan Konservasi Alam IV(5) : 467 - 483.

Iswandono, E. 2007. Analisis Pemanfaatan dan Potensi Sumberdaya Tumbuhan di Taman Wisata Alam Ruteng, Nusa Tenggara Timur. Tesis Sekolah Pasca Sarjana Institut Pertanian Bogor. Bogor. $172 \mathrm{~h}$. 
Kadir, A., S.A. Awang, R.H. Purwanto, E. Poedjiraharjoe. 2012. Analisis Kondisi Sosial Ekonomi Masyarakat Sekitar Taman Nasional Bantimurung Bulusaraung, Provinsi Sulawesi Selatan. Jurnal Manusia dan Lingkungan 19(1) : 1 - 11 .

Munawaroh, E., R. Saparita, Y. Purwanto. Ketergantungan Masyarakat Pada Hasil Hutan Non Kayu di Malinau, Kalimantan Timur: Suatu Analisis Etnobotani Dan Implikasinya Bagi Konservasi Hutan. Berkl. Penelitian Hayati Edisi Khusus 7A(51-58).

Rahmat, M., Hamdi. 2007. Pendapatan Masyarakat dari Hutan dan FaktorFaktor Sosial Ekonomi yang Mempengaruhinya : Kasus Desa
Penyangga TNKS di Kabupaten Pesisir Selatan. Jurnal Penelitian Sosial dan Ekonomi Kehutanan 4(2) : $193-204$.

Soehartono, I. 2002. Metode Penelitian Sosial Suatu Teknik Penelitian Bidang Kesejahteraan Sosial dan Ilmu Sosial Lainnya. Remaja Rosdakarya Offset. Bandung. 103 h.

Uluk, A., M. Sudana, E. Wollenberg, 2001. Ketergantungan Masyarakat Dayak terhadap Hutan di Sekitar Taman Nasional Kayan Mentarang. Center for International Forestry Research (CIFOR). Bogor. $150 \mathrm{~h}$.

Wirartha, I.M. 2006. Metodologi Penelitian Sosial Ekonomi. Ed I. Andi Offset. Yogyakarta. $390 \mathrm{~h}$. 